\title{
SPECIAL ASPECTS OF SPECIFYING CONSTRUCTIONS AT THE LEVEL OF A SIMPLE COMPLICATED SENTENCE
}

\author{
Olha Novikova \\ PhD in Philology, Senior Lecturer at the Department of Social Disciplines and Humanities, \\ Donetsk Law Institute of the Ministry of Internal Affairs of Ukraine, Ukraine \\ e-mail: 08novikovaolga76@gmail.com,orcid.org/0000-0002-8498-1736
}

\section{Summary}

The article deals with the topical issues associated with the formation of the category of specification, examines various aspects of the study of specifying syntactic constructions, describes their structure, meaning, functions, characterizes differential features, typological manifestations. It has been established that specifying syntactic units are in the system relations with other types of explanatory constructions (self-clarification, concretization). The author has found out the difference between specifying and self-explanatory syntactic units. Specifying constructions should be distinguished from self-explanatory as the former realizes clarifying semantics through narrowing, scope limitation while the latter designates the same concept, phenomenon, feature but denotes it in diverse ways. The meaning of specification is peculiar to one of two, commonly, one-level syntactic unit, integrative in content. The availability of "the whole to part relation" within the specifying constructions doesn't require relevant conjunctions for their expression, and thus, they are characterized by asyndeton. It has also been marked other, less expressive means - intonation separation close to intonation of listing and parenthesis, specifiers (точніше, правильніше, краще) in combination with word forms (сказати, кажучи) or without them. Specifying constructions have been classified according to the morphological manifestation of a root component (substantive, adjective, adverbial, verbum finitum). The research has proved that the above constructions can be used as any part of a sentence (they usually act as an adverbial modifier of time and place).

Keywords: syntactic unit, explanatory constructions, self-explanation, specification, concretization.

DOI: https://doi.org/10.23856/4008

\section{Introduction}

The concept of specification is used in linguistics, at least, in two meanings. In a broad sense, this is any information which implements additional characteristics. V. H. Admoni regards specification in a semantic-syntactic link (Admoni, 1964). In such a context, every subordinate part enlarging a sentence always clarifies its content, enriches semantically, increases options of explicit expression of a particular idea. It essential to draw the line between a broad sense of specification, which takes place among different formations (for instance, word combinations, complex sentences, formations with specifiers, appositions) (Selivanova, 2008: 134; Kadomtseva, 1972: 231; Vykhovanets, 1992: 351), and specification in the terminological sense, which is mainly associated with the constructions under analysis (traditionally - with the specifying parts of a sentence). In a narrow sense, specification is a special category of the semantic-syntactic character. M. M. Shanskyi was a pioneer who introduced the concept of specification as a syntactic phenomenon in linguistics emphasizing that "specification as an 
explanatory part acts in a sentence as...separated, usually after a member which it explains or defines, and can be attached to any member" (Shanskyi, 1958: 92). Over a short period, the concept of specification has taken roots in the scientific use as a kind of separation in the structure of a simple complicated sentence. Scientists differ over the interpretation of this concept: "specification" (Shanskyi, 1958: 87), "detached specifying parts of a sentence" (Kulyk, 1961: 162), "explanatory detached phrases" (Shvedova, 1980: 181), "explanatory-specifying phrases" (Slynka, 1994: 363), "intermediate syntactic link” (Rozental, 1972: 26-27; Kobchenko, 2018 : 18-26), "syntactic specifier" (Vintoniv, 2018: 71-74) etc. However, at the moment, there is no clear definition of this concept.

The purpose of the article is to analyze the structural and functional characteristics of specifying constructions in the modern Ukrainian language. To achieve the purpose, it is incumbent to solve the following tasks: to find out the structure, semantics of specifying syntactic units, to determine their functional and stylistic peculiarities in the texts of the modern Ukrainian literary language.

\section{Analysis of the recent research and publications}

The following philologists dealt with the study of specifying constructions: I. M. Aribzhanova, T. A. Aleksandrova, M. D. Akhmedkhanova, I. R. Vykhovanets, A. P. Zahnitko, B. M. Kulyk, M. Ya. Oleniak, A. F. Pryiatkina, I. I. Slynko, N. S. Fomina, T. B. Funtova, V. I. Chuhlov et al. The authors examined different aspects of the above syntactic units, including their typology, functions, structural-semantic features etc. Nowadays, the issue of semantic and grammatical differentiation of specifying and explanatory syntactic constructions remains contradictory to scientific literature. Some of researchers don't mark the distinction between the concepts of explanation and specification, but unite them into one group (Moisiienko, 2009; Shvedova, 1980; Huivaniuk, 1994). "Russian grammar" dated 1980 designates such constructions by a broader term - explanatory detached phrases, because the specification is one of the types of explanation -the whole to part relation (Shvedova, 1980: 181). I. I. Slynko, N. V. Huivaniuk, M. F. Kobylianska use the concept of explanatory-specifying phrases which treat as detached constructions associated with different parts of a sentence by the special explanatory or specifying link (Slynko, 1994: 364). A. K. Moisiienko also considers explanatory and specifying constructions to be of the same type and ascribes them to one type - self-explanatory syntactic units (A. K. Moisiienko, 2009: 26). However, there are papers which consistently confirm the idea of the need to draw the line between these two concepts (Aribzhanova, 2011; Vintoniv, 2018; Oleniak, 2011; Pryiatkyna, 1990; Funtova, 2002; Chuhlov, 2012).

\section{Explanatory syntactic units}

Self-explanation emerges between two parts of a sentence which designate the same concept, phenomenon, feature but denote it differently (self-explanations is based on identity), е.g.: Надвечір ӥй, себто Соломії, почувся дим (M. Kotsiubynskyi). Specification is a semantic and syntactic category which realizes specifying semantics through narrowing, limitation of information scope of two syntactic units compared in content (the second member of a line more precisely defines what the first member denotes) (Shvedova, 1980: 176). Specification always includes additional information, e.g.: Напередодні, 29 листопада, Сльцинн надсилає «другу Біллу» листа (Holos Ukrainy, 12.10.2019). As opposed to explanation, specification is not associated with an undetermined meaning of a specified word (cf.: Напередодні, 
29 листопада, Єльциин надсилає «другу Біллу» листа $\leftarrow$ Напередодні Сльциин надсилає «другу Біллу» листа + 29 листопада Сльцинн надсилає «другу Біллу» листа - specification (period identity is not marked, information scope is limited); Надвечір ӥй, себто Соломї, почувся дим Ł Надвечір їй почувся дим + Надвечір Соломії почувся дим - self-explanation (identity is emphasized and rendered using себто that confirms explanation). Specifying and specified components don't double each other in terms of syntax position - they are not interchangeable.

Specifying construction is a syntactic unit which contains specified and specifying components and acts as a syntactic form realizing the semantics of specification of a particular part of a sentence. Specification provides for a more thorough scope of information mentioned in the above context in order to reach a bigger correspondence of content of a phrase with reality and communicative tasks. It functions as a means of concretization (limitation) of content (the whole to part relation), which has already been expressed grammatically, and semantically formed unit by changing information scope.

Specifying parts don't realize their meaning outside a syntactic construction. The meaning of specification is peculiar only to one of two, usually one-level, syntactic unit integrative in content. At the same time, the meaning of specification emerges solely in case of relevant syntactic relations and requires special structural arrangement. A specifying component is always in postposition and detached, e.g.: У нас багато маленьких шкіл, здебільшого сільських (Dzerkalo tyzhnia, 07.12.2019); А ось до 2010-го - цілих вісім років - я працювала саме 8 Українському домі (Holos Ukrainy, 12.10.2019), На жаль, колектив у нас дуже маленький, утричі менший від необхідного (Dzerkalo tyzhnia, 07.12.2019).

\section{Structural expressions of specifying constructions}

The availability of "the whole to part relation" within the specifying constructions doesn't need special conjunctions for their expressing as they would be redundant. Thus, specification as a syntactic category is characterized by asyndeton, e.g.: Поляна ия, подзьобана струхлявілими пеньками, викружилася край осичняка, трохи на згірку (Ye. Hutsalo); На трьох поняттях - свобода, гідність і рівність - побудовано всю Свропу (Uriadovyі kurier, 23.10.2019).

A relative independence is usually inherent in specifying constructions that explains their intonational transformation into the constructions without clarification, e.g.: Це був великий звір з иирокими грудьми (Ye. Hutsalo); Вдень забігали вуличні пси, обнюхували всі ці сліди любові й заклопотано вибігали назад на центральні вулиці міста (S. Zhadan). Reading of such sentences is possible both with separating intonation and without it. O. M. Pieshkovskyi paid attention to an alternative of such use in his day: "we can just say одного разу восени він захворів» (Pieshkovskyi, 1956: 420). O. M. Hvozdiev has stressed that adverbial modifiers of place may be a combination of two individual notions of place: «... На столі в саду вже стояв кошик з яблуками». Such constructions can represent "close combination" without expressing their (conditions) relations" (Hvozdiev, 1968: 124).

As syntactic units with conjunctions as syntactic units involving asyndeton - in this case, it refers to specifying syntactic constructions - are characterized by less expressive means: first of all, intonational separation close to intonation of enumeration and parentheses, and specifiers точніше, правильніше, краще in combination with word forms сказати, кажучи or without them, e.g.: А 21 листопада стали відомими результати конкурсу на зазначену посаду, точніше - їх відсутність (Dzerkalo tyzhnia, 07.12.2019); Нашим завданням було 
забезпечити умови, точніше - знайти фінансування (S. Zhadan); Шахтарі до кінця року отримають надані урядом гроші, точніше додаткові 322,6 мільйона гривень на погашення заборгованості із зарплатні (Uriadovyi kurier, 21.12.2019); Знайтла вона обох поляків у бідності, точніше сказати - у страшних злиднях (O. Honchar). As well as other categories of explanatory constructions, these formations have their peculiarities of double denotation of a subject.

\section{Classification features of specifying constructions}

The classification of specifying constructions according to the morphological manifestation of a root component has become widespread in modern linguistic theory (Shvedova, 1980: 181; Slynko, 1994: 365-374). It is conventional to differentiate the following types of specifying syntactic units:

- substantive, e.g.: На тому боці, ген під обрієм, примостилося село (Ye. Hutsalo); Його хата стояла край села, на пагорбі (Ulas Samchuk); $\boldsymbol{A}$ там, на Україні, в холонучих садах ще світяться жоржини з крижинками в очах (M. Kotsiubynskyi); Перед дуплом, на порозі своєї хижі, сич струснув із себе краплі дошу і повільно, вайлувато пробрався на постіль з пір'я та сухого листя (Н. Tiutiunnyk); Так, щце за часи наших пращурів, наприкінці XVII століття, у документах з'являсться слово «закон» (Dzerkalo tyzhnia, 12.11.2019); У степу, кілометрів за двадцять від Жовтого Яру, можна побачити ияю історичну пам'ятку (Uriadovyi kurier, 23.10.2019).

- adjective, e.g.: Льолік уже терся коло холодильника в своєму костюмі, старенькому, старанно випрасуваному (S. Zhadan); 3 цьього, південного, боку економія мала не зовсім привабливий вигляд (О. Honchar);.Цієї зими дерева взагалі особливі чутливі, сполохані, мов тварини, здригаються на кожен вибух, тримають у собі своє тепло, не вимерзають, прогрівають довкола себе чорні лунки, в яких темно зеленіє стара трава (Ye. Hutsalo); А за ним іде другий, зовсім молодий, сопливий якийсь, із червоними, злими й припухлими очима (S. Zhadan); Нажаль, колектив у нас дуже маленький, утричі менший від необхідного (Dzerkalo tyzhnia, 07.12.2019); Це вже було щзось нове, нечуване для каховського ярмарку (O. Honchar);

- adverbial, e.g.: А за вікнами десятки очей так само, по-пташиному-приречено й прискіпливо, - пильнують за кожним його рухом, за кожним його кроком (S. Zhadan); Але й це в нього виходило якось особливо, по-панському (O. Honchar); I ось сьогодні врешті-решт, увечері, всіма членами комісії було підписано ией довгоочікуваний контракт (Uriadovyi kurier, 11.10.2019); Звідти, десь звисока, впало на нього світло, розріджене, скупе (O. Honchar); Учора, десь опівночі, прийшов з кіньли стариий Слисеїв син, також Василь (Ulas Samchuk);

- verbum finitum, e.g.: Востанне Паша їхав на таксі місяцьь тому - повертався з міста (S. Zhadan); Раніше в політииі, у будь-якій серйозній справі, жінкам не давали можллиості реалізувати себе - робили їм на кожному кроці перепони (Dzerkalo tyzhnia, 11.10.2019). Далі юрби розривалися - звертали в провулки й пропадали в темряві (A. Holovko); Артем послухав цуе мовчки й знов став клепати - рогача Орисі справляв (A. Holovko).

Scientific studies focus on limited use of specifying constructions within the syntactic functions of the parts of a sentence. In particular, "Directory of linguistic terms" emphasizes: "adverbial modifiers of place and time usually fulfil a clarifying role, and specifying adverbial modifiers of manner are less widespread", "constructions which indicate a size, color, form and 
other object features also act as specifying members" (Rozental, 1972: 459). Admitting the first part of the characteristics, in the context of the second, the author states that specifying constructions can be used in terms of any part of a sentence as well, for instance, as subject: Квimu, точніше - пальми і аспарагуси, відразу навіяли життя у мертві кімнати (Liuko Dashvar); object: Він звернув увагу на платани, точніше на їхнс листя, понищене гусінню (O. Honchar); I голос його щуирим відгуком забринів у селянських серцях, точніше в серцях молоді (M. Stelmakh) etc.

One of the significant features of the analyzed constructions is an option to have a range of consequent specifications realized in speech as a range of specifying components, е.g.: У метафорі, у їі значенні, точніше кажучи - у самій основі їі значення - три елементи (from a book); Пташка сиділа на дереві, на кремезному дубі, на зламаній гілці (Ye. Hutsalo); I щзось там, за воротами, просто на землі, міжс подертими комбінезонами й перемащеним ганчір'ям (S. Zhadan); Зустрінемося в університеті, у бібліотеці, у читальній залі, за останнім столом (S. Zhadan). The mentioned feature of specifying constructions is not just specific to the analyzed syntactic units, it is expressed in semantics and, particularly, in the structure of double (sometimes triple etc.) designation of an object. In the semantic framework, it is expressed by a differing degree of semantic distance of a specifying component from specified, cf.: (зустрінемося) в університеті, у бібліотеці $\check{u}$... в університеті, за останнім столом у читальній залі. This is the way for determining both the consistency and certain conceptual and syntactic coherence, "involuntary nature" of a double meaning.

\section{Functional expression of specifying syntactic units}

Linguistic papers attribute the functions of concretization and limitation as well as the function of additional clarification to the primary functions of specifying constructions (Pryiatkyna, 1990: 76-77; Zahnitko, 2011: 568-569). In the author's opinion, the function of clarification is insufficiently substantiated, and thus, it should be attributed to the competence of the relevant kind of explanatory constructions (concretizing syntactic units). It is obvious that the function of limitation differs from the function of additional clarification by a degree of expression. The third function, which represents a wide semantic diversity of specification, deserves a particular attention because as A. F. Pryiatkina rightly notes "... a specified component is always different, new, additional" (Pryiatkyna, 1990: 75-76).

\section{Conclusions}

Specifying syntactic constructions are in the system relations with other kinds of explanatory constructions (self-clarification, concretization). Specifying constructions should be distinguished from self-explanatory as the former realizes specifying semantics through narrowing, scope limitation while the latter designates the same concept, phenomenon, feature but names it differently. The meaning of specification is peculiar to one of two, commonly, onelevel syntactic unit, integrative in content. The availability of "the whole to part relation" within the specifying constructions doesn't require special conjunctions for their expression, and thus, they are characterized by asyndeton. Specifying constructions have been classified according to the morphological manifestation of the root component (substantive, adjective, adverbial, verbum finitum). It has been proved that the analyzed constructions can be used as any part of a sentence (they usually act as an adverbial modifier of time and place). The primary function of 
the constructions under study is the function of additional clarification, which represents a wide semantic diversity of specifications. Directions for future research involve studying special aspects of the functioning of concretizing syntactic units as a kind of explanatory constructions at the level of a simple complicated sentence.

\section{References}

Admoni, V. G. (1964). Osnovy teorii grammatiki [Grammar Theory]. M.-L.: Nauka. [in Russian]. Aribzhanova, I. (2011). Clarification as a Syntactic Notion [Refinement as a syntactic concept]. Ukrainian Linguistics. № 42. [in Ukrainian].

Akhmedkhanova, M. D. (1998). Utochniaiushchie konstruktcii, ikh tipy i stilisticheskie funktcii v proze N. S. Leskova [Clarifying structures, their Types and stylistic functions in prose N. S. Leskov.]. (Dissertation of PhD). Dagestanskii gosudarstvennyi universitet. Makhachkala. [in Russian].

Chuglov, V.I. (2012). Oslozhnennoe predlozhenie: polupredikativnye i poiasnitelnye konstruktcii v sovremennom russkom literaturnom iazyke (strukturno-semanticheskii aspekt) [Complicated sentence: semi-predictive and explanatory constructions in the modern Russian literary language (structural and semantic aspect)]. (Extended abstract of $D$ dissertation). Volgogradskii gosudarstvennyi pedagogicheskii universitet. Iaroslavl. [in Russian].

Fomina, N. S. (2009). Sintaksicheskie konkretizatory kak stileobrazuyushchee sredstvo v proze N. S. Leskova [Syntactic concretizers as an instrument of style formation in N. S. Leskov's prose]. (Dissertation of PhD). Petrozavodskiy gosudarstvennyy universitet. Petrozavodsk. [in Russian].

Funtova, T. B. (2002). Lohiko-syntaksychna katehoriia utochnennia v suchasnii rosiiskii movi (semantyka, zasoby vyrazhennia) [The logical-syntactic category of refinement in modern Russian (semantics, means of expression)]. (Extended abstract of PhD dissertation). Simferopol. [in Ukrainian].

Galkina-Fedoruk, E. M., Gorshkova, K. V., Shanskii, N. M. (1958). Sovremennyi russkii iazyk: Sintaksis [Modern Russian: Syntax.]. Moskva. [in Russian].

Gvozdev, A. N. (1968). Sovremennyi russkii literaturnyi iazyk. Ch II. Sintaksis [Modern Russian literary language. Part II. Syntax]. Moskva: Prosveshchenie. [in Russian].

Kadomtseva, L. O. (1972). Syntaksychno izolovani chastyny rechennia [Syntactically isolated parts of a sentence] / Suchasna ukrainska literaturna mova / Za zah. red. I. K. Bilodida. Kyiv. [in Ukrainian].

Kobchenko, N. (2018). Hramatychna pryroda oposeredkovanoho syntaksychnoho zv'iazku $v$ strukturi prostoho rechennia [The grammatical nature of the semi-predictive syntax in the structure of a simple sentence]. Naukovi zapysky NaUKMA. Movoznavstvo. Tom 1. [in Ukrainian]. Kulyk, B. M. (1961). Kurs suchasnoi ukrainskoi literaturnoi movy [Course of modern Ukrainian literary language. Part 2: Syntax] v 2 ch. Kyiv: Radianska shkola. Ch. 2: Syntaksys. [in Ukrainian].

Moisiienko, A. K. (2009). Suchasna ukrainska mova. Syntaksys prostoho uskladnenoho rechennia [Modern Ukrainian language. The syntax of a complicated sentence]. Kyiv. [in Ukrainian]. Oleniak, M. Ya. (2011). Semantyko-syntaksychni funktsii utochnennia v anhliiskii, ukrainskii ta polskii movakh [Semantics-syntactic functions of refinement in English, Ukrainian and Polish]. (Extended abstract of PhD dissertation). Donetskyi natsionalnyi universytet. Donetsk: DonNU. [in Ukrainian]. 
Peshkovskii, A. M. (1956). Russkii sintaksis v nauchnom osveshchenii [Russian syntax in scientific lighting]. Moska: Uchpedgiz. [in Russian],

Priyatkina, A. F. (1990). Russkyi yazyk: Syntaksys oslozhnennoho predlozhenyia [Russian language: Complicated sentence syntax]. Moscow: Vysshaia shkola. [in Russian].

Rozental, D. E., Telenkova, M. A. (1972). Spravochnik lingvisticheskikh terminov [Directory of linguistic terms.]. Moskva: Prosveshchenie. [in Russian].

Russkaia hrammatyka [Russian grammar]. (1980). Moscow: Nauka. [in Russian].

Selivanova, O. (2008). Suchasna linhvistyka: napriamy ta problemy [Modern linguistics: directions and problems]: pidruchnyk. Poltava: Dovkillia-K. [in Ukrainian].

Slynko, I. I., Huivaniuk, N. V., Kobylianska, M. F. (1994). Syntaksys suchasnoi ukrainskoi movy. Problemni pytannia [Syntax of the modern Ukrainian language. Problematic issues]. Kyiv: Vyshcha shkola. [in Ukrainian].

Vykhovanets, I. R. (1992). Narysy z funktsionalnoho syntaksysu ukrainskoi movy [Essays on the functional syntax of the Ukrainian language]. Kyiv: Naukova dumka. [in Ukrainian].

Vintoniv, M. O., Aksonova, I. O. (2018). Typolohiini vyiavy syntaksychnykh konkretyzatoriv u suchasnii ukrainskii movi [Typology of syntactic concretizers in modern Ukrainian]. Science and Education a New Dimension. Philology. VI (47). [in Ukrainian].

Zahnitko, A. P. (2011). Teoretychna hramatyka suchasnoi ukrainskoi movy. Morfolohiia. Syntaksys [Theoretical grammar of modern Ukrainian. Morphology. Syntax]. Donetsk: TOV "VKF “BAO”. [in Ukrainian]. 